\title{
The Maternalists
}


INTELLECTUAL HISTORY

OF THE MODERN AGE

Series Editors

Angus Burgin

Peter E. Gordon

Joel Isaac

Karuna Mantena

Samuel Moyn

Jennifer Ratner-Rosenhagen

Camille Robcis

Sophia Rosenfeld 


\section{THE MATERNALISTS}

Psychoanalysis, Motherhood, and the British Welfare State

Shaul Bar-Haim

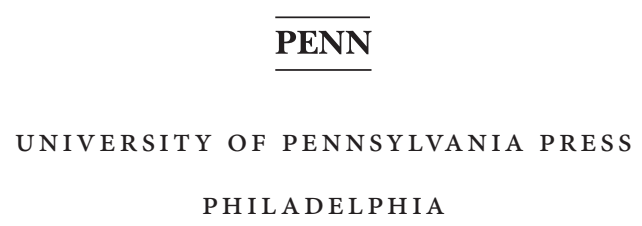


Copyright $\odot 2021$ University of Pennsylvania Press

All rights reserved.

Except for brief quotations used for purposes of review or scholarly citation, none of this book may be reproduced in any form by any means without written permission from the publisher.

Published by

University of Pennsylvania Press

Philadelphia, Pennsylvania 19104-4112

www.upenn.edu/pennpress

Printed in the United States of America on acid-free paper

109876543221

A Cataloging-in-Publication record is available from the

Library of Congress

ISBN 978-0-8122-5315-3 
In memory of my mother, Rachel Bar-Haim (1946-2013) 
